\title{
PENGARUH CONSUMER KNOWLEDGE, BRAND IMAGE, RELIGIUSITAS, DAN LOKASI TERHADAP KEPUTUSAN MENJADI NASABAH PADA BANK SYARIAH
}

\author{
Afrian Rachmawati \\ Program Studi Ekonomi Syariah, ITB Ahmad Dahlan Jakarta, afrian.rachmawati@gmail.com
}

\begin{abstract}
This research is aimed at analysing the influence of consumer knowledge, brand image, religiousity, and location to any decision to be sharia bank's customer by using 4 hypotheses to be examined using SEM method. The research sample includes 212 respondents. Results of SEM analysis meets criteria of goodness of fit index with marginal. Results of this research show that consumer knowledge with product type, product use, and product benefit indicators do not significantly influence the decision to be sharia bank's customer. Brand image with product attribute, consumer benefit, and brand personality indicators do not significantly influence the decision to be sharia bank's customer. Religiousity with ritual, ideology, intellectual, experience, and consequence indicators do not significantly influence any decision to be sharia bank's customer. Location with location accessibility, location smoothness, and location proximity indicators significantly influence any decision to be sharia bank's customer.
\end{abstract}

Keywords : Consumer Knowledge, Brand Image, Religiousity, Location, Decision to Be Customer, Sharia Bank. 


\begin{abstract}
ABSTRAK
Penelitian ini bertujuan untuk menganalisis consumer knowledge, brand image, religiusitas, dan lokasi terhadap keputusan menjadi nasabah bank syariah. Dengan menggunakan 4 hipotesis untuk diuji dengan metode SEM. Sampel penelitian ini adalah 212 orang responden. Hasil analisis SEM memenuhi kriteria goodness of fit index dengan marginal. Hasil penelitian ini menunjukkan bahwa consumer knowledge dengan indikator jenis produk, manfaat produk dan benefit produk tidak berpengaruh signifikan terhadap keputusan menjadi nasabah bank syariah. Brand image dengan indikator atribut produk, keuntungan konsumen, dan kepribadian merek tidak berpengaruh signifikan terhadap keputusan menjadi nasabah bank syariah. Religiusitas dengan indikator ritual, ideologis, intelektual, pengalaman, dan konsekuensi tidak berpengaruh signifikan terhadap keputusan menjadi nasabah bank syariah. Lokasi dengan indikator keterjangkauan lokasi, kelancaran lokasi, dan kedekatan lokasi berpengaruh signifikan terhadap keputusan menjadi nasabah bank syariah.
\end{abstract}

Kata Kunci : Consumer Knowledge, Brand Image, Religiusitas, Lokasi, Keputusan Menjadi Nasabah, Bank Syariah. 


\section{PENDAHULUAN}

Pemerintah dalam upaya meningkatkan pertumbuhan ekonomi untuk meningkatkan taraf hidup masyarakatnya dan melakukan pembangunan pada sektor ekonomi demi memajukan ekonomi umat. Upaya ini memberikan dampak pada industri keuangan dengan bermunculannya lembaga keuangan yang dipandang sesuai dengan syariat islam. Sejarah keberadaan bank syariah dalam sistem perbankan Indonesia sebenarnya telah dikembangkan sejak tahun 1992 ditandai dengan berdirinya bank Muamalat, dan sejalan diberlakukannya Undang-undang No. 7 Tahun 1992 Tentang perbankan, sebagaimana telah di ubah dengan Undang-undang No. 10 Tahun 1998. Namun demikian Undang-undang tersebut belum memberikan landasan hukum yang cukup kuat terhadap pengembangan bank syariah karena belum secara tegas mencantumkan kata prinsip syariah dalam kegiatan usaha bank. Pada perkembangannya perbankan syariah di Indonesia tidak terlepas dari sistem perbankan konvensional yang sebelumnya memang sudah berkembang di Indonesia terlebih dahulu.

Perkembangan perbankan syariah di Indonesia tidak luput dari perkembangan industri keuangan syariah yang diawali dari inspirasi masyarakat Indonesia yang mayoritas muslim untuk memiliki sebuah alternatif sistem perbankan yang islami. Tantangan perbankan syariah di Indonesia masih sangat panjang dimana harus bisa merebut pangsa pasar yang selama ini di domisili oleh perbankan konvesional. Berdasarkan snapsot OJK Juni 2018. Market Share perbankan syariah 5.70\% dari total perbankan nasional. Dengan porsi Bank Umum Syariah 66.22\%, Unit Usaha Syariah 31.25\%, dan BPR Syariah 2.53\%. Ada 1.827 jumlah kantor Bank Syariah, UUS 349 kantor, dan BPRS ada 459 kantor. Dilihat dari aset Bank Syariah memiliki aset tertinggi dibandingkand engan UUS dan BPRS. Dari sisi Pembiayaan Bank Syariah lebih besar dibanding UUS dan BPRS. Untuk DPK Bank Syariah paling diminati untuk tabungan dibandingkan dengan UUS.

Hal ini berkaitan dengan apa yang terjadi dimasyarakat awam masih mempertanyakan apakah ada perbedaan bank syariah dan konvesional itu sendiri. Tidak hanya itu, sebagian lagi masyarakat sudah mulai memahami apa itu bank syariah, dan apa yang membedakannya dengan bank konvesional. Namun masih awam mengenai produk yang dimilikinya, sehingga menyebabkan masyarakat enggan menggunakan produk-produk yang ditawarkan namun hanya diminati bagi masyarakat yang ingin menabung untuk menghindari adanya unsur riba. Padahal fasilitas yang ditawarkan oleh bank syariah tidak kalah unggul dengan bank konvensional.

Penelitian ini memfokuskan dalam penyebaran kuesioner di daerah Banten, sebagai provinsi dengan jumlah mayoritas muslim sebesar $94.62 \%$ dari total penduduk 12.448 .160 jiwa. Hal ini berkaitan dengan besarnya potensi market bagi perbankan syariah untuk mengembangkan bisnisnya di wilayah Provinsi Banten. Aset perbankan syariah di provinsi Banten dalam kurun waktu 4(empat) tahun terakhir meningkat. Pada 2018 aset perbankan syariah di provinsi banten 14.658 Miliar atau meningkat dari periode sebelumnya. Sedangkan pembiayaan mengalami kenaikan dibandingkan dengan tahun 2017 sebesar 14.658 Miliar dari 
tahun sebelumnya. Sedangkan dari sisi DPK pada 2018 perbankan Provinsi Banten dapat menghimpun dana sebesar 12.760 Miliar meningkat dibandingkan tahun sebelumnya.

Dilihat dari distribusi dan sebaran pencapaian kinerja keuangan perbankan umum berdasarkan Kota/Kabupaten di Provinsi Banten, sebagian besar DPK yang dihimpun oleh perbankan syariah di Provinsi Banten berdasarkan Kota/Kabupaten, maka DPK dari Kota Tangerang menyumbang tertinggi dengan volume mencapai Rp. 5.596 Miliar atau 43,86\% dari total DPK di Provinsi Banten. Kabupaten Tangerang memberikan kontribusi DPK terbesar kedua dengan volume mencapai 3.839 Miliar atau sebesar 30.09\% dari total DPK di Provinsi Banten, selanjutnya disusul oleh Kabupaten Serang dengan volume DPK sebesar 1.424 Miliar atau sebesar $11.06 \%$ dari DPK di Banten.

DPK berpengaruh pada keputusan nasabah untuk menggunakan jasa bank syariah tersebut. Keputusan yang diambil merupakan keputusan nasabah dalam memilih bank sebagai tempat untuk menabung dan sebagainya. Ada beberapa pengaruh yang melatarbelakangi nasabah dalam memutuskan menjadi nasabah perbankan syariah berasal dari luar maupun dari nasabah itu sendiri. Faktor-faktor yang mempengaruhi preferensi nasabah dalam menggunakan layanan perbankan syariah yang dipilih, yaitu: pertama, pengetahuan yang dipahami nasabah menjadi faktor yang mempengaruhi preferensi nasabah dalam memilih layanan perbankan syariah. Menurut Kamus Besar Bahasa Indonesia, pengetahuan adalah sesuatu yang diketahui atau segala sesuatu tentang suatu hal. Secara umum, pengetahuan konsumen mengenai bank syariah mencakup pengetahuan produk, pelayanan, serta pengetahuan tentang penerapan nilai-nilai syariah oleh perbankan syariah.

Kedua, Brand Image adalah apa yang konsumen pikirkan dan rasakan ketika mendengar atau melihat sebuah brand. Menurut Susanto 2008 (dalam nugroho, 2011) brand image adalah apa yang dipresepsikan oleh konsumen mengenai sebuah merek. Dimana hal itu menyangkut bagaimana seorang konsumen menggambarkan apa yang mereka rasakan mengenai merek tersebut ketika mereka memikirkannya.

Ketiga religiusitas merupakan tingkat keterikatan individu terhadap agamanya. Apabila individu telah menghayati dan menginternalisasikan ajaran agamanya, maka ajaran agamanya akan berpengaruh dalam segala tindakan dan pandangan hidup. Salah satunya yaitu memilih menjadi nasabah salah satu bank syariah. Keempat keterjangkauan lokasi yang ditempuh merupakan salah satu alasan mengapa nasabah memilih bank tersebut.

Dalam hal ini persepsi masyarakat awam dan orang-orang mengenal bank syariah dari luarnya saja, yaitu memandang bank syariah sama saja dengan bank konvesional. Hal ini sangat disayangkan, karena notabene penduduk Indonesia mayoritas muslim, dan seharusnya pertumbuhan dan perkembangan bank syariah di Indonesia bisa lebih cepat. Jika pengetahuan tentang bank syariah rendah maka dalam memandang dan keinginan untuk menjadi nasabah bank syariah pastinya rendah pula. Sedangkan pengetahuan tentang bank syariah tinggi maka dalam memandang dan keinginan untuk menjadi nasabah bank syariah pastinya tinggi.

Maka dengan penelitian ini saya menganggap betapa pentingnya menganalisa faktor yang mempengaruhi seorang nasabah untuk mengambil keputusan menggunakan jasa suatu 
bank syariah. Perbankan syariah harus melakukan upaya dalam meningkatkan jumlah nasabah selain motivasi adalah dengan mempelajari dan mengamati hal-hal yang mempengaruhi pengambilan keputusan nasabah untuk menggunakan jasa suatu bank syariah. Karena nasabah merupakan pusat perhatian perusahaan, maka faktor yang dapat memberikan pengaruh pada keputusan nasabah dalam memilih bank syariah di daerah Banten.

\section{LITERATUR REVIEW}

\section{Perilaku Konsumen}

Menurut Philip Kotler (2005: 183) "Perilaku konsumen menurut Kotler merupakan suatu proses penilaian dan pemilihan dari berbagai alternatif sesuai dengan kepentingankepentingan tertentu dengan menetapkan suatu pilihan yang dianggap paling menguntungkan." Winardi mengartikan perilaku konsumen sebagai perilaku yang ditujukan oleh orang-orang dalam hal merencanakan, membeli, dan menggunakan barang-barang ekonomi dan jasa. Berdasarkan beberapa pengertian di atas dapat disimpulkan bahwa perilaku konsumen berkaitan erat dengan proses pengambilan keputusan untuk menggunakan barang dan atau jasa untuk memuaskan kebutuhannya.

Menurut Kotler dan Amstrong, faktor-faktor yang mempengaruhi tingkah laku konsumen terdiri dari :

1. Faktor Kebudayaan

2. Faktor Sosial

3. Faktor Pribadi

4. Faktor Psikologi

\section{Pengambilan Keputusan}

Menurut Richard L. Daft pengambilan keputusan adalah "Proses dalam mengenali masalah-masalah dan peluang-peluang untuk kemudian dipecahkan." Dan menurut Marimin (2005:12) Mengambil atau membuat keputusan adalah suatu proses yang dilaksanakan orang berdasarkan pengetahuan dan informasi yang ada padanya pada saat tersebut dengan harapan bahwa sesuatu akan terjadi. Keputusan dapat diambil dari alternatif-alternatif keputusan yang ada. Alternatif keputusan tersebut dapat dilakukan dengan adanya informasi yang diolah dan disajikan dengan sistem penunjang keputusan.

\section{Consumer Knowledge}

Menurut John C. Mowen dan Michael Minor (2002: 135) menjelaskan bahwa: "Pengetahuan konsumen (customer knowledge) telah didefinisikan sebagai sejumlah pengalaman dengan dan informasi tentang produk atau jasa tertentu yang dimiliki oleh seseorang. Dengan meningkatnya pengetahuan konsumen individu, hal ini memungkinkan bagi konsumen tersebut untuk berfikir tentang produk di antara sejumlah dimensi yang lebih besar dan membuat perbedaan yang baik diantara merek-merek. Menurut Mowen dan Minor, 
pengetahuan konsumen dibedakan menajdi pengetahuan informasi lain. Engel, Blackwell dan Miniard menggambarkan pengetahuan sebagai informasi yang disimpan seseorang didalam memori otaknya, sebagian informasi tersebut berfungsi bagi konsumen untuk mengenali pasar dan hal tersebut disebut sebagai pengetahuan konsumen.

Pengetahuan produk menurut Peter dan Olson dibedakan menjadi antara lain:

1. Pengetahuan tentang karakteristik atau atribut produk berupa warna, model, tahun, dan lain-lain. Ada dua macam atribut menggambarkan ciri-ciri suatu produk dan atribut abstrak yang menggambarkan karakteristisk produk berdasarkan persepsi konsumen.

2. Pengetahuan tentang manfaat produk

3. Pengetahuan tentang kepuasan yang diberikan produk bagi konsumen.

\section{Brand image}

Brand image atau citra merek adalah dua istilah yang sama. Yaitu kesan terhadap merek. Brand yang berarti merek dan image adalah kesan. Sedangkan citra merek adalah pencitraan terhadap merek. Pada penelitian ini akan digunakan istilah brand image. Menurut Keler 2000 (dalam Ferrinadewi 2008) "Brand image adalah persepsi tentang merek yang merupakan refleksi memori konsumen akan asosiasinya pada merek tersebut." Sedangkan menurut Susanto 2008 (dalam Nugroho, 2011) brand image adalah apa yang dipersepsikan oleh konsumen mengenai sebuah merek. Dimana hal ini menyangkut bagaimana seorang konsumen menggambarkan apa yang mereka rasakan mengenai merek tersebut ketika mereka memikirkannya.

Terdiri beberapa pendapat tentang komponen dari brand image yaitu Menurut Joseph Plummer 1992 (dalam Ratri, 2007), brand image terdiri dari tiga komponen, yaitu:

1. Product attributes (Atribut produk) yang merupakan hal-hal yang berkaitan dengan merek tersebut sendiri, seperti kemasan, isi produk,harga, rasa, dan lain-lain.

2. Consumer benefits (Keuntungan konsumen) yang merupakan kegunaan produk dari merek tersebut.

3. Brand personality (Kepribadian merek) merupakan asosiasi yang mengenai kepribadian sebuah merek apabila merek tersebut adalah manusia.

\section{Religiusitas}

Menurut Nourcholis Majid 2006 (dalam Sahlan, 2012), agama bukanlah sekedar tindakan-tindakan ritual seperti shalat dan membaca do'a. Agama lebih dari itu, yaitu keseluruhan tingkah laku manusia yang terpuji, yang dilakukan demi memperoleh ridha atau perkenan Allah. Menurut (Muhaimin, 2002) religiusitas adalah pengabdian terhadap agama, kesalehan. Keberagamaan atau religiusitas lebih melihat aspek di dalam lubuk hati nurani pribadi, sikap personal yang misterius karena menafaskan intimitas jiwa, etika rasa yang mencakup totalitas (termasuk rasio dan rasa manusiawi) ke dalam pribadi manusia. Karena itu pada dasarnya religiusitas lebih dari agama yang tampak formal dan resmi.

Ada lima dimensi keberagamaan sesorang yang dapat diukur untuk mengetahui 
apakah seseorang tersebut religius atau tidak, yaitu, dimensi keyakinan, dimensi praktek agama (ritual dan ketaatan), dimensi pengalaman, dimensi pengetahuan agama, dimensi pengamalan atau konsekuensi. Dalam konteks sebagai agama yang dianut oleh mayoritas masyarakat Indonesia, lima dimensi tersebut dapat dijelaskan sebagi berikut :

1) Dimensi Ritual; yaitu aspek yang mengukur sejauh mana seseorang melakukan kewajiban ritualnya dalam agama yang dianut. Misalnya; pergi ke tempat ibadah, berdoa pribadi, berpuasa, dan lain-lain. Dimensi ritual ini merupakan perilaku keberagamaan yang berupa peribadatan yang berbentuk upacara keagamaan.

2) Dimensi Ideologis; yang mengukur tingkatan sejauh mana seseorang menerima halhal yang bersifar dogmatis dalam agamanya. Misalnya; menerima keberadaan Tuhan, malaikat dan setan, surga dan neraka, dan lain-lain. Dalam konteks ajaran Islam, dimensi ideologis ini menyangkut kepercayaan seseorang terhadap kebenaran agamaagamanya. Semua ajaran yang bermuara dari Al quran dan hadits harus menjadi pedoman bagi segala bidang kehidupan. Keberagaman ditinjau dari segi ini misalnya mendarmabaktikan diri terhadap masyarakat yang menyampaikan amar ma'ruf nahi mungkar dan amaliah lainnya dilakukan dengan ikhlas berdasarkan keimanan yang tinggi.

3) Dimensi Intelektual; yaitu tentang seberapa jauh seseorang mengetahui, mengerti, dan paham tentang ajaran agamanya, dan sejauh mana seseorang itu mau melakukan aktivitas untuk semakin menambah pemahamannya dalam hal keagamaan yang berkaitan dengan agamanya. Secara lebih luas, Dimensi intelektual ini menunjukkan tingkat pemahaman seseorang terhadap doktrin-doktrin agama tentang kedalaman ajaran agama yang dipeluknya. Ilmu yang dimiliki seseorang akan menjadikannya lebih luas wawasan berfikirnya sehingga perilaku keberagamaan akan lebih terarah.

4) Dimensi Pengalaman; berkaitan dengan seberapa jauh tingkat Muslim dalam merasakan dan mengalami perasaan-perasaan dan pengalaman religius. Dalam Islam dimensi ini terwujud dalam perasaan dekat dengan Allah, perasaan doa-doanya sering terkabul, perasaan tentram bahagia karena menuhankan Allah, perasaan bertawakkal, perasaan khusuk ketika melaksanakan sholat, perasaan tergetar ketika mendengar adzan atau ayat-ayat al-qur'an, perasaan syukur kepada Allah, perasaan mendapat peringatan atau pertolongan dari Allah.

5) Dimensi Konsekuensi; Dalam hal ini berkaitan dengan sejauh mana seseorang itu mau berkomitmen dengan ajaran agamanya dalam kehidupan sehari-hari. Misalnya; menolong orang lain, bersikap jujur, mau berbagi, tidak mencuri, dan lain-lain. Aspek ini berbeda dengan aspek ritual. Aspek ritual lebih pada perilaku keagamaan yang bersifat penyembahan/adorasi sedangkan aspek komitmen lebih mengarah pada hubungan manusia tersebut dengan sesamanya dalam kerangka agama yang dianut. Pada hakekatnya, dimensi konsekuensi ini lebih dekat dengan aspek sosial. Dimensi sosial adalah menifestasi ajaran agama dalam kehidupan masyarakat, meliputi semua perilaku yang didefinisikan oleh agama (Rahmat, 1986:37). Ditinjau dari dimensi ini 
semua aktivitas yang berhubungan dengan kemasyarakatan umum merupakan ibadah. Hal ini tidak lepas dari ajaran Islam yang menyeluruh, menyangkut semua sendi kehidupan. Jadi religiusitas pada dasarnya merupakan perbuatan seseorang yang berhubungan dengan masyarakat luas dalam rangka mengembangkan kreativitas pengabdian (ibadah) kepada Allah semata.

\section{Lokasi}

Pengertian Lokasi menurut KBBI (Kamus Besar Bahasa Indonesia) adalah letak atau tempat. Sedangkan pengertian lokasi menurut para ahli adalah :

a) Teori lokasi dari August Losch (dalam Sofa, 2008) melihat persoalan dari sisi permintaan (pasar). Losch mengatakan bahwa lokasi penjual sangat berpengaruh terhadap jumlah konsumen yang dapat digarapnya. Makin jauh dari tempat penjual, konsumen makin enggan membeli karena biaya transportasi untuk mendatangi tempat penjual semakin mahal.

b) Menurut Kotler (2008:51) Salah satu kunci menuju sukses adalah lokasi, lokasi dimulai dengan memilih komunitas. Keputusan ini sangat bergantung pada potensi pertumbuhan ekonomis dan stabilitas, persaingan, iklim politik, dan sebagainya.

c) Lokasi menurut Lupiyoadi (2009:42), berhubungan dengan di mana perusahaan harus bermarkas dan melakukan operasi atau kegiatannya.

d) Menurut Fandy Tjiptono (2006) dalam penelitian Aprih Santoso dan Sri Widowati (2011: 183) variable lokasi lebih memakai indikator berikut :

(1) Keterjangkauan lokasi.

(2) Kelancaran akses menuju lokasi.

(3) Kedekatan lokasi.

\section{Kerangka Pemikiran Teoritis dan Pengembangan Hipotesis}

Hal ini membuktikan bahwa consumer knowledge, brand image, religiusitas, dan lokasi berpengaruh signifikan terhadap keputusan menjadi nasabah di Bank Syariah. Demikian halnya dengan keputusan menjadi nasabah perbankan syariah pada penelitian ini, difokuskan pada faktor yang mempengaruhinya adalah consumer knowledge, brand image religiusitas, dan lokasi. Berdasarkan uraian diatas tersebut maka maka dikembangkan sebuah kerangka pemikiran teoritis, seperti dibawah ini yaitu sebagai berikut :

\section{H1 : Diduga Consumer Knowledge berpengaruh positif terhadap keputusan menjadi nasabah bank syariah.}

Mowen dan Minor mendefinisikan pengetahuan konsumen sebagai suatu jumlah pengalaman dan informasi yang seseorang ketahui tentang barang atau jasa tertentu. Pengetahuan produk terbagi menjadi tiga jenis menurut ahli yang membaginya. Pengetahuan konsumen dalam memutuskan menjadi nasabah bank syariah juga didasari oleh pengetahuan 
konsumen tersebut tentang bank syariah itu sendiri. Semakin meraka memahami bank syariah semakin mereka yakin bahwa memang syariah berbeda dengan bank konvesional.

\section{H2 : Diduga Brand Image berpengaruh positif terhadap keputusan menjadi nasabah bank syariah.}

Hal berikutnya yang di perhatikan calon nasabah dalam memilih bank syariah yaitu Brand Image dari bank syariah tersebut. Hasil penelitian Eko Yuliawan sependapat bahwa pengetahuan konsumen berpengaruh terhadap keputusan menjadi nasabah. Brand image adalah persepsi tentang merek yang merupakan refleksi konsumen akan asosiasinya pada merek tersebut. konsep yang diciptakan oleh konsumen karena alasan subyektif dan emosi pribadinya. Ketika calon konsumen melihat brand image bank tersebut memang baik dan menarik, hal ini sangat berpengaruh dalam memilih menjadi nasabah bank tersebut. Hasil dari penelitian Ngakan Putu Surya Adi Dharma dan I Putu Gede Sukaatmadja, bahwa Citra merek (brand image) berpengaruh positif dan signifikan terhadap keputusan pembelian produk Apple.

\section{H3 : Diduga Religiusitas berpengaruh positif terhadap keputusan menjadi nasabah bank syariah.}

Selanjutnya Religiusitas yaitu konsep multi dimensi yang meliputi keimanan atau kepercayaan dan perilaku yang didasarkan pada pikiran dan perbuatan seseorang. Tingkat religiusitas seorang terhadap perilaku untuk memilih suatu yang dibolehkan atau dilarang oleh agama islam sangatlah berpengaruh. Apabila seorang tersebut tingkat religiusitasnya rendah, maka tidak akan mempertimbangkan hal-hal yang dilarang oleh agama islam, sebaliknya apabila tingkat religiusitas seseorang tinggi, maka seseorang tersebut akan menjauhi hal-hal yang dilarang dan akan menjalankan hal-hal yang diperbolehkan oleh agama islam. Tidak terkecuali dalam minat seseorang untuk memilih suatu produk barang atau jasa. Hal ini sependapat dengan hasil dari penelitian Rika Yulianti, Marijati Sangen dan Ahmad Rivani bahwa Nilai-nilai Agama berpengaruh signifikan terhadap keputusan menjadi nasabah Bank.

\section{H4 :Diduga Lokasi berpengaruh positif terhadap eputusan menjadi nasabah bank syariah.}

Lalu pengaruh selanjutnya adalah lokasi bank syariah tersebut, semakin mudah diaksesnya lokasi bank syariah tersebut semakin banyak minat calon nasabah untuk menajdi nasabah bank syariah itu sendiri. 


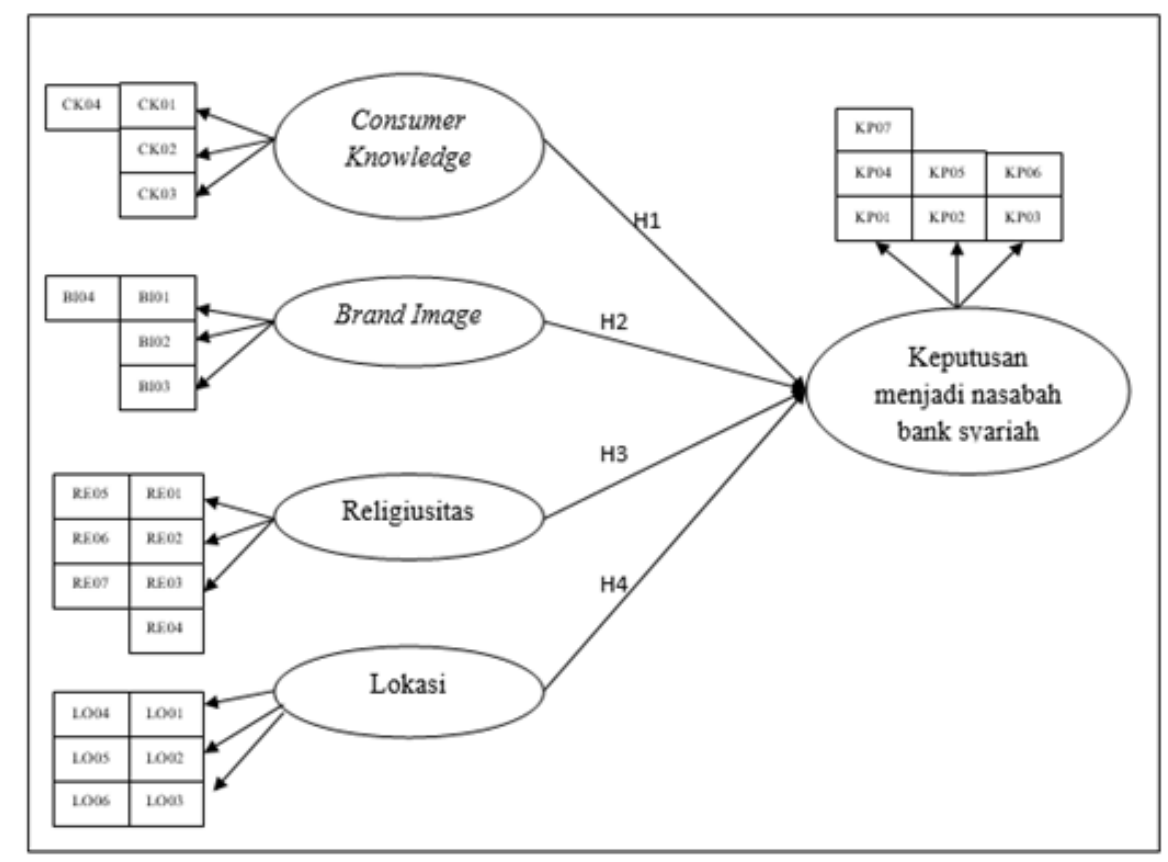

Gambar 1. Hipotesis Penelitian

Adapun indikator variabel dalam penelitian ini disajikan dalam tabel berikut ini :

\section{Tabel 1. Indikator Variabel}

\begin{tabular}{|c|c|}
\hline Variabel & Indikator \\
\hline \multirow{3}{*}{$\begin{array}{l}\text { Consumer } \\
\text { Knowledge }\end{array}$} & Jenis Produk \\
\hline & Manfaat Produk \\
\hline & Benefit Produk \\
\hline \multirow{3}{*}{ Brand Image } & Atribut produk \\
\hline & Keuntungan konsumen \\
\hline & Kepribadian merek \\
\hline \multirow{5}{*}{ Religiusitas } & Ritual \\
\hline & Ideologis \\
\hline & Intelektual \\
\hline & Pengalaman \\
\hline & Konsekuensi \\
\hline \multirow{3}{*}{$\begin{array}{l}\text { Keterjangkau } \\
\text { Lokasi }\end{array}$} & Keterjangkauan lokasi \\
\hline & $\begin{array}{l}\text { Kelancaran akses menuju } \\
\text { lokasi }\end{array}$ \\
\hline & Kedekatan lokasi \\
\hline \multirow{3}{*}{$\begin{array}{c}\text { Keputusan } \\
\text { Menjadi Nasabah }\end{array}$} & Budaya \\
\hline & Sosial \\
\hline & Pribadi \\
\hline
\end{tabular}




\section{METODE}

Populasi dalam penelitian ini adalah masyarakat Banten. Menurut Sugiyono (2017: 81) teknik sampling merupakan teknik pengambilan sampel. Mengenai ukuran sampel minimal dengan dalam analisis SEM, menurut Hair et al. (Kusnendi 2008: 54) menyatakan jika dalam model yang dianalisa ada 5 (lima) konstruk atau kurang di mana masing-masing konstruk diukur minimal oleh 3 (tiga) indikator maka diperlukan ukuran sampel minimal antara 100300 observasi. Dengan Penyebaran 300 kuesioner melalui google form. Periode pengamatan dilakukan pada Januari sampai dengan februari 2019.

\section{Teknik pengumpulan data}

Menurut Sujarweni (2014: 74) menjelaskan bahwa Teknik pengumpulan data adalah cara yang dilakukan peneliti untuk mengungkapkan atau menjaring informasi kuantitatif dari responden sesuai lingkup penelitian.

\section{Data Primer}

Penyebaran Kuesioner adalah seperangkat pertanyaan yang diberikan secara langsung kepada responden untuk di isi sebagai alas untuk mengukur sikap atau intensitas pendapat masyarakat (Silaen dan Widiyono, 2013:126). Digunakan pendekatan Skala Likert. Langkah-langkah penggunaan skala likert diawali dengan penjabaran variabel menjadi beberapa dimensi, kemudian masing-masing dimensi di jabarkan menjadi beberapa indicator.

\section{Data Sekunder}

Data yang diambil dalam penelitian ini adalah data sekunder, yaitu data yang diperoleh secara tidak langsung dari perusahaan yang dijadikan unit analisis dengan menggunakan teknik sebagai berikut:

a. Penelitian Kepustakaan (Library Research) memperoleh data sekunder penulis melakukan studi kepustakaan yang dilakukan untuk memperoleh landasan teoritis yang berhubungan dengan masalah yang diteliti. Dilakukan dengan cara membaca, mengkaji, meneliti, dan menelaah literatur-literatur berupa jurnal-jurnal, buku maupun makalah yang berhubungan erat dengan topik perubahan laba, sehingga diperoleh informasi sebagai dasar teori dan acuan untuk mengolah data-data yang diperoleh di lapangan.

b. Riset Internet (Online Research) pada penelitian ini penulis berusaha memperoleh berbagai data dan informasi lainnya yang berhubungan dan dapat mendukung penelitian ini.

\section{Operasional Variabel}

Berdasarkan perumusan masalah, uraian teoritis dan hipotesis yang diajukan, maka variabel-variabel dalam penelitian ini sebagai berikut : 


\section{Variabel Independen (X)}

Variable bebas $(\mathrm{X})$ variable ini sering disebut sebagai variable stimulus, predictor, abtecedent. Dalam bahasa Indonesia sering disebut variabel bebas. variabel bebas adalah variabel yang mempengaruhi atau yang menjadi sebab perubahannya atau timbulnya variabel dependen (terikat). (Sugiyono, 2017 :39). Dalam penelitian ini variabel independen yang diteliti adalah consumer knowledge, brand image, religiusitas dan lokasi.

\section{Variabel Dependen (Y)}

Variable terikat adalah variabel yang dipengaruhi atau yang menjadi akibat, karena adanya variabel bebas (Sugiyono, 2017 : 39). Dalam penelitian ini variabel independen yang diteliti adalah keputusan menjadi nasabah di bank syariah.

\section{HASIL DAN PEMBAHASAN}

\section{Gambaran umum Perbankan Syariah di Banten}

Banten dengan luas 9.662,92 km2 dengan tingkat kepadatan penduduk 1.288 jiwa/km2, dan dibagi menjadi 4 Kabupaten dan 4 Kota yang meliputi : Kabupaten Pandeglang, Kabupaten Lebak, Kabupaten Tangerang, Kabupaten Serang, Kota Tangerang, Kota Cilegon, Kota Serang, Kota Tangerang Selatan.

\section{Responden}

Pengumumpulan data dilakukan 2 bulan dari bulan januari sampai dengan februari 2019. Dari kuesioner yang sebar via google form jumlah total yang disebar 300 kuesioner, kuesioner yang kembali sebanyak 270 lalu diolah kembali sehingga kuesioner yang lengkap dan siap diolah 212 kuesioner.

\section{Uji Measurement Model}

Gambar berikut menunjukkan hubungan indikator dan unobserved variable. 


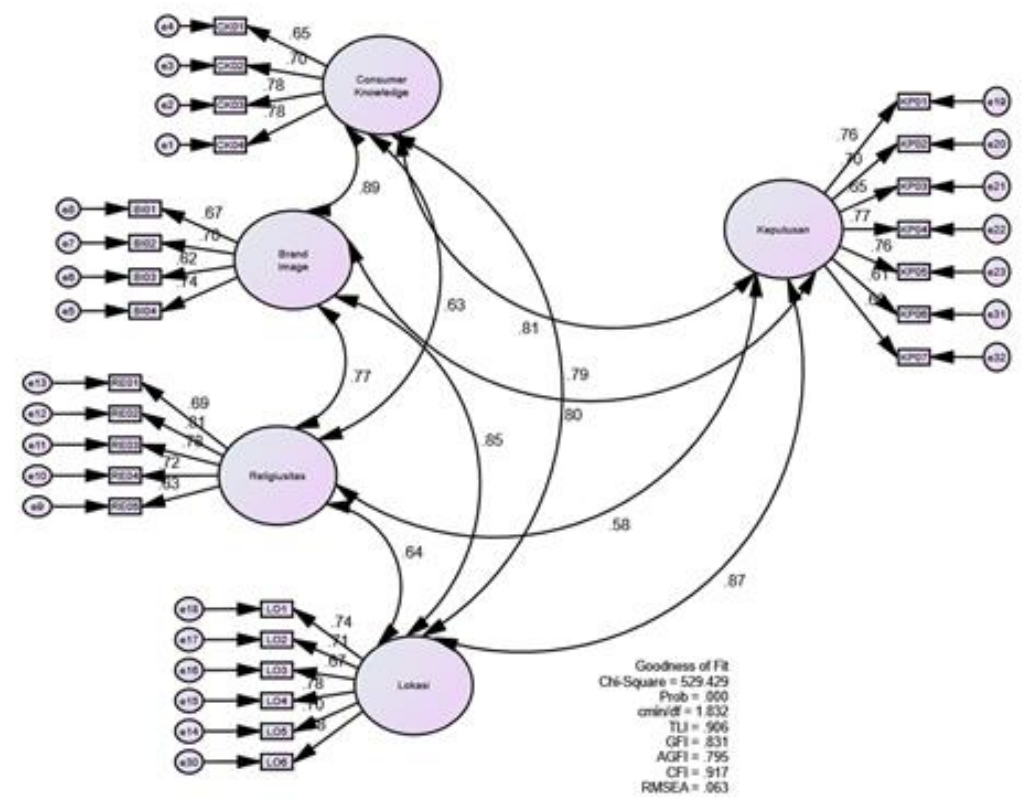

Gambar 2. Uji Measurement Model

Beberapa indikator menunjukkan hubungan indicator engan konstruknya masingmasing. Loading Faktor yang digunakan untuk mengukur konstribusi masing-masing indicator bila nilainya diatas 0.50 , maka dikatan indicator iu cukup representative untuk menerangkan unobserved variabelnya. Oleh sebab itu semua data diatas dianggap memenuhi dan dapat diproses ke proses selanjutnya.

Tabel 2. Loading Factor Variabel Consumer Knowledge

\begin{tabular}{|c|c|c|c|}
\hline \multicolumn{2}{|c|}{ Indikator } & Variabel & \multirow{2}{*}{$\begin{array}{l}\text { Loading } \\
\text { Factor } \\
.654\end{array}$} \\
\hline CK01 & --- & Consumer_Knowledge & \\
\hline CK02 & --- & Consumer_Knowledge & .700 \\
\hline CK03 & --- & Consumer_Knowledge & .785 \\
\hline CK04 & --- & Consumer_Knowledge & .776 \\
\hline
\end{tabular}

Loading factor variabel Consumer Knowledge dengan indikator jenis produk, manfaat produk dan benefit produk. Indikator yang memiliki skor tertinggi adalah pada indikator manfaat produk CK03 yaitu 0,785, yang berarti sub variabel ini memberi kontribusi sebesar 78,5\% terhadap variabel Consumer Knowledge. Artinya jika perbankan syariah di Banten 
ingin meningkatkan Consumer Knowledge, maka salah satu yang harus diperhatikan adalah indikator manfaat produk.

Tabel 3. Loading Factor Variabel Brand Image

\begin{tabular}{|l|l|l|l|}
\hline Indikator & \multicolumn{2}{|l|}{ Variabel } & $\begin{array}{l}\text { Loading } \\
\text { Factor }\end{array}$ \\
\hline BI01 & & Brand_Image & .668 \\
\hline BI02 & --- & & \\
\hline BI03 & --- & Brand_Image & .699 \\
\hline BI04 & --- & Brand_Image & .618 \\
\hline & --- & Brand_Image & .738 \\
\hline
\end{tabular}

Loading factor variabel Brand Image dengan indikator atribut produk, keuntungan konsumen, dan kepribadian merek. Indikator yang memiliki skor tertinggi adalah pada indikator kepribadian merek BI04 yaitu 0,738, yang berarti sub variabel ini memberi kontribusi sebesar 73,8\% terhadap variabel Brand Image. Artinya jika perbankan syariah di Banten ingin meningkatkan Brand Image, maka salah satu yang harus diperhatikan adalah indikator kepribadian merek.

Tabel 4. Loading Factor Variabel Religiusitas

\begin{tabular}{|l|l|l|l|}
\hline Indikator & \multicolumn{2}{|l|}{ Variabel } & $\begin{array}{l}\text { Loading } \\
\text { Factor }\end{array}$ \\
\hline RE01 & & Religiusitas & .694 \\
\hline RE02 & --- & & \\
\hline RE03 & --- & Religiusitas & .814 \\
\hline RE04 & --- & Religiusitas & .778 \\
\hline RE05 & --- & Religiusitas & .716 \\
\hline & --- & & \\
\hline
\end{tabular}


Loading factor variabel Religiusitas dengan indikator ritual, ideologis, intelektual, pengalaman, dan konsekuensi. Indikator yang memiliki skor tertinggi adalah pada indikator ideologis RE02 yaitu 0,814, yang berarti sub variabel ini memberi kontribusi sebesar 81,4\% terhadap variabel Religiusitas. Artinya jika perbankan syariah di Banten ingin meningkatkan Religiusitas, maka salah satu yang harus diperhatikan adalah indikator ideologis.

Tabel 5. Loading Factor Variabel Lokasi

\begin{tabular}{|l|l|l|l|}
\hline Indikator & & Variabel & $\begin{array}{l}\text { Loading } \\
\text { Factor }\end{array}$ \\
\hline LO1 & --- & Lokasi & .735 \\
\hline LO2 & & Lokasi & .712 \\
\hline LO3 & --- & & \\
\hline LO4 & --- & Lokasi & .670 \\
\hline LO5 & --- & Lokasi & .779 \\
\hline LO6 & - & Lokasi & .703 \\
\hline
\end{tabular}

Loading factor variabel Lokasi dengan indikator keterjangkauan lokasi, kelancaran lokasi, dan kedekatan lokasi. Indikator yang memiliki skor tertinggi adalah pada indikator kelancaran lokasi LO04 yaitu 0,779, yang berarti sub variabel ini memberi kontribusi sebesar 77,9\% terhadap variabel Lokasi. Artinya jika perbankan syariah di Banten ingin meningkatkan Lokasi, maka salah satu yang harus diperhatikan adalah indikator kelancaran lokasi.

Tabel 6. Loading Factor Variabel Keputusan Memilih Bank Syariah

\begin{tabular}{|c|c|c|c|}
\hline Indikator & & Variabel & $\begin{array}{l}\text { Loading } \\
\text { Factor }\end{array}$ \\
\hline KP01 & --- & Keputusan & .763 \\
\hline
\end{tabular}




\begin{tabular}{|l|l|l|l|}
\hline KP02 & & Keputusan & .700 \\
\hline KP03 & --- & & \\
& --- & Keputusan & .655 \\
\hline KP04 & & Keputusan & .774 \\
\hline KP05 & --- & & \\
\hline KP06 & --- & Keputusan & .759 \\
& --- & Keputusan & .612 \\
\hline KP07 & & Keputusan & .629 \\
& --- & & \\
\hline
\end{tabular}

Loading factor variabel Keputusan Memilih Bank Syariah dengan indikator budaya, sosial, dan pribadi. Indikator yang memiliki skor tertinggi adalah pada indikator budaya KP01 yaitu 0,763 , yang berarti sub variabel ini memberi kontribusi sebesar 76,3\% terhadap variabel Keputusan Memilih Bank Syariah. Artinya jika perbankan syariah di Banten ingin meningkatkan Keputusan Memilih Bank Syariah, maka salah satu yang harus diperhatikan adalah indikator budaya.

\section{Analisis Structural Equation Modeling}

Analisis ini selanjutnya adalah Structural Equation Modeling (SEM) secara full model yang dimaksudnya untuk menguji model dan hipotesis yang dikembangkan dalam penelitian ini. Pengujian model dalam Structural Equation Modeling (SEM) dilakukkan dengan dua pengujian, yaitu uji kesusaian model dan uji signifikasi kausalitas melalu uji koefisien regresi. Hasil pengolahan data untuk analisis Structural Equation Modeling (SEM) terlihat pada Gambar 3 dibawah ini: 


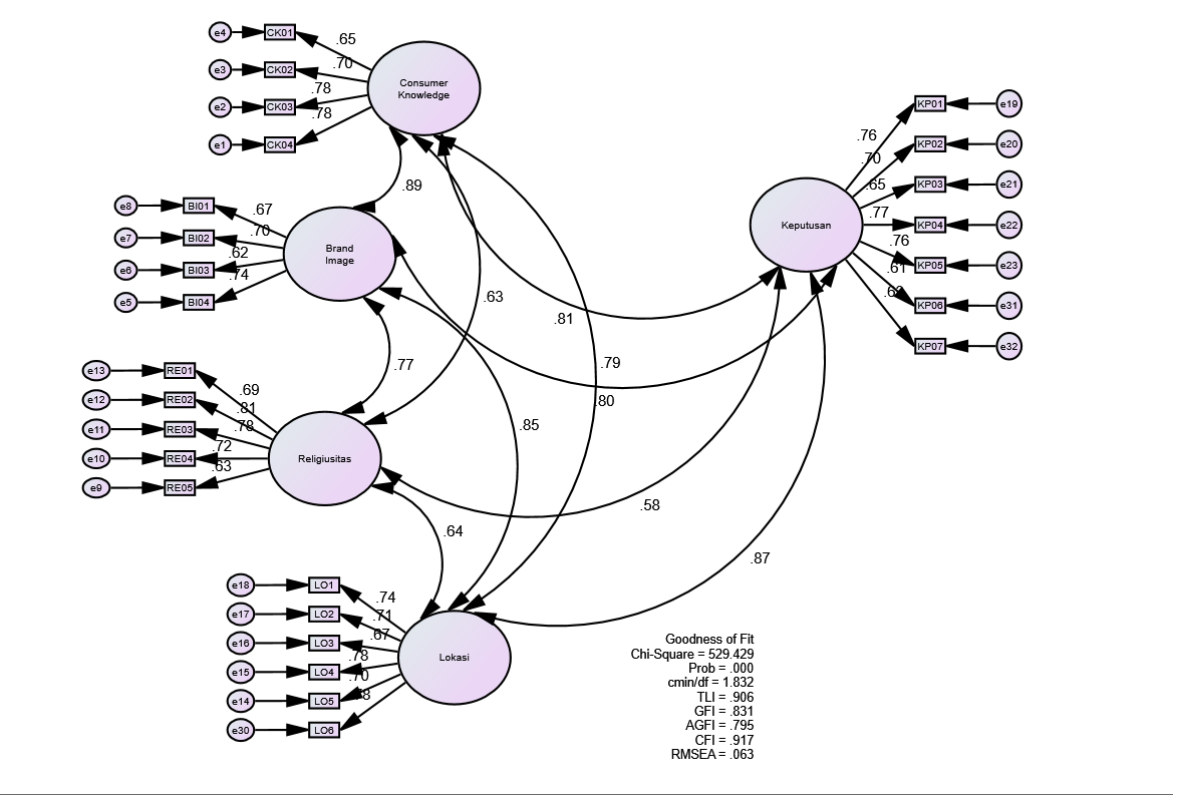

Gambar 3. Structural Equation Modeling (SEM)

\section{Pengujian Hipotesis}

Pengujian hipotesis ini didasarkan atas pengolahan data penelitian dengan menggunakan analisis Structural Equation Modeling (SEM), denga cara menganalisis nilai regresi (Regression Weights Analisis Structural Equation Modeling).

Tabel 6. Hubungan Antar Konstruks

\begin{tabular}{|c|c|c|c|}
\hline \multicolumn{3}{|c|}{ Hubungan Konstruk } & Estimate \\
\hline Keputusan & $<---$ & Consumer_Knowledge & .379 \\
\hline Keputusan & $<--$ & Brand_Image & -.112 \\
\hline Keputusan & $<--$ & Religiusitas & .003 \\
\hline Keputusan & $<--$ & Lokasi & .805 \\
\hline
\end{tabular}

Pengujian hipotesis ini adalah dengan menganalisis nilai Critical Rasio (CR) dan nilai Probablity (P) hasil olah data, dibandingkan dengan batasan statistic yang di syaratkan, yaitu diatas 1,96 untuk nilai CR dan dibawah 0,05 untuk P (Probablity).

Tabel 7. Kesimpulan Hipotesis

\section{HIPOTESIS}

\section{Nilai CR HASIL dan $P$ UJI}




\begin{tabular}{|c|c|c|c|c|}
\hline \multirow[b]{2}{*}{1} & \multirow{2}{*}{$\begin{array}{l}\text { Consumer Knowledge } \\
\text { berpengaruh positif terhadap } \\
\text { keputusan menjadi nasabah } \\
\text { bank syariah }\end{array}$} & $\mathrm{R}$ & ,710 & Ditolak \\
\hline & & & ,087 & \\
\hline \multirow{2}{*}{2} & \multirow[t]{2}{*}{$\begin{array}{l}\text { Brand Image berpengaruh } \\
\text { positif terhadap keputusan } \\
\text { menjadi nasabah bank syariah }\end{array}$} & $\mathrm{R}$ & $\begin{array}{r}0,32 \\
2\end{array}$ & Ditolak \\
\hline & & & ,747 & \\
\hline \multirow{2}{*}{3} & \multirow[t]{2}{*}{$\begin{array}{l}\text { Religiusitas berpengaruh } \\
\text { positif terhadap keputusan } \\
\text { menjadi nasabah bank syariah }\end{array}$} & $\mathrm{R}$ & ,016 & Ditolak \\
\hline & & & ,987 & \\
\hline \multirow{2}{*}{4} & \multirow[t]{2}{*}{$\begin{array}{l}\text { Lokasi berpengaruh positif } \\
\text { terhadap keputusan menjadi } \\
\text { nasabah bank syariah }\end{array}$} & $\mathrm{R}$ & ,864 & Diterima \\
\hline & & &, 000 & \\
\hline
\end{tabular}

\section{SIMPULAN}

1. Consumer knowledge dengan indikator jenis produk, manfaat produk dan benefit produk tidak berpengaruh signifikan terhadap keputusan menjadi nasabah bank syariah.

2. Brand image dengan indikator atribut produk, keuntungan konsumen, dan kepribadian merek tidak berpengaruh signifikan terhadap keputusan menjadi nasabah bank syariah.

3. Religiusitas dengan indikator ritual, ideologis, intelektual, pengalaman, dan konsekuensi tidak berpengaruh signifikan terhadap keputusan menjadi nasabah bank syariah.

4. Lokasi dengan indikator keterjangkauan lokasi, kelancaran lokasi, dan kedekatan lokasi berpengaruh signifikan terhadap keputusan menjadi nasabah bank syariah.

\section{REFERENSI}

Undang-Undang Republik Indonesia Nomor 7 Tahun 1992 Tentang Perbankan. Undang-Undang Republik Indonesia Nomor 10 Tahun 1998 Tentang Perubahan Atas Undang-Undang Republik Indonesia Nomor 7 Tahun 1992 Tentang Perbankan. 
Undang-Undang Republik Indonesia Nomor 21 Tahun 2008 Tentang Perbankan Syariah.

Ancok, Jamaludin dan Fuad Anshari Suroso, 2001. Psikologi Islam : Solusi Islam Atas Problema- ProblemaPsSikologi, Pustaka Pelajar, Yogyakarta. Rahmat, Jalaludin, Islam Aletrnatif, Bandung, Mizan, 1986.

Ali Syukron, "Dinamika Perkembangan Perbankan Syariah di Indonesia", Jurnal Ekonomi dan Hukum Islam, Vol. 3, No. 2, (2013), 29.

Basu Swastha dan Hani Handoko, Perilaku Konsumen, BPFE, Yogyakarta, 2004.

Danang Suntoyo, Perilaku Konsumen (Panduan Riset Sederhana untuk Mengenali Konsumen), (Yogyakarta: Center of Academi Publishing Service, 2013).

Daniel Ortega dan Anas Alhifni, "Pengaruh Media Promosi Perbankan Syariah terhadap Minat Menabung Masyarakat Di Bank Syariah", Equilibrium: Jurnal Ekonomi Syariah, Vol. 5, No. 1, (2017), 87-89. P-ISSN 2355-0228 E-ISSN 2502-8316.

Eko Yuliawan, " Pengaruh Pengetahuan Konsumen Mengenai Perbankan Syariah Terhadap Keputusan Menjadi Nasabah Pada PT. Bank Syariah Cabang Bandung”, Jurnal Wira Ekonomi Mikroskil, Vol. 1, No. 1, (April, 2011), 21.

Hermawan Kartajaya, Op. Cit, hlm. 4.

John C. Mowen dan Michael Minor, Perilaku Konsumen Jilid I, (Jakarta: PT. Penerbit Erlangga,2002) hal.135

Kuncoro, Mudrajat. 2013. Metode riset untuk bisnis dan ekonomi. Bagaimana meneliti dan menulis tesis? Edisi Empat. Jakarta: Erlangga.

Ngakan Putu Surya Adi Dharma dan I Putu Gde Sukaatmadja, " Pengaruh Citra Merek, Kesadaran Merek, dan Kulitas Produk Terhadap Keputusan Membeli Produk Apple.”, E-Jurnal Manajemen Unud, Vol. 4, No. 10, P- ISSN:2302 -8912.

Marimin, Teknik dan Aplikasi Pengambilan keputusan Kriteria Majemuk, (Jakarta: PT Grasindo, 2005), 12.

Makhdaleva Hanura Tajudin, Ade Sofyan Mulazid, " Pengaruh Promosi, Kepercayaan dan Kesadaran Merek Terhadap Keputusan Nasabah Menggunakan Produk Tabungan Haji (Mabrur) Bank Syariah Mandiri KCP. Sawangan Kota Depok", Jurnal Ekonomi Islam, Vol. 8, No. 1, (Januari-Juni 2017), P-ISSN: 2085-3696; E-ISSN: 2541-4127. Page: 19 $-46$

Megawaty, “Analisis Pengetahuan Konsumen Mengenai Perbankan Syariah dan Pengaruhnya Terhadap Keputusan Menjadi Nasabah Pada PT. Bank Tabungan Negara Syariah ( PERSERO) Cabang Makassar", Dosen STIM Nitro Makassar. 103

Muhammad Syafi'i Antonio (2007), Bank Syariah dari Teori ke Praktik. Jakarta: Gema Insan Press. Cetakan ke-2.

Mutiara Dewi Sari, "Perkembangan Perbankan Syariah di Indonesia: Suatu Tinjauan", Jurnal Aplikasi Bisnis, Vol. 3, No. 2, (April, 2013), 123.

Philip Kotler, Manajemen Pemasaran, (Jakarta: Indeks, 2005), 183.

Philip Kotler dan G Amstrong, Prinsip-prinsip Pemasaran, edisi kedelapan, (Jakarta: Erlangga, 2001),197. 
Philip Kotler dan Kevin Lane Keller, Manajemen Pemasaran Edisi 12, (Jakarta: Erlangga, 2006), 252.

Rambat Lupiyoadi, Manajemen Pemasaran Jasa teori dan Praktik, Salemba Empat, Jakarta, 2001, hlm. 161.

Rangkuti, Freddy. 2009. The power of brand, teknik mengelola brand equity dan strategi pengembangan merek. Jakarta: Gramedia.

Rika Yulianti, Marijati Sangen dan Ahmad Rivani, " Pengaruh Nilai-nilai Agama, Kualitas Layanan, Promosi, danKepercayaan Terhadap Keputusan Menjadi Nasabah Bank Syariah Di Banjarmasin”, Jurnal Wawasan Manajemen, Vol. 4, No. 2, Juni 2016.

Richard L. Daft, Era Baru Manajemen, (Jakarta: Salemba, 2010), 283

Rismis Somad dan Donni Juni Priansa, Manajemen Komunikasi Mengembangkan Bisnis Berorinetsi Pelanggan,(Bandung:Alfabeta,2014). Hal.107

Silaen, Sofar dan Widiyono. 2013. Metodologi penelitian sosial untuk penulisan skripsi dan tesis. Jakarta: In Media.

Sorayanti Utami, "The Influence Of Customers"e Trust On Customer Loyalty", International Journal of Economics, Commerce and Management United Kingdom Vol. III, Issue 7, July 2015, Dept. of Management, Faculty of Economics, University of Syiah Kuala, Darussalam, Banda Aceh, Indonesia, hlm. 645.

Sudarsono, Heri. 2008. Bank dan Lembaga Keuangan Syariah. Yogyakarta: Ekonisia. Cetakan ke -2 .

Sugiyono, (2017). Metode penelitian bisnis. Bandung: Alfabeta, Cetakan ke Dua Puluh Enam.

Sujarweni, V. Wiratna. 2014. Metode Penelitian: Lengkap, Praktis, dan Mudah Dipahami. Yogyakarta: Pustaka Baru Press.

Syahriyal, "Pengaruh Persepsi Nilai dan Pengetahuan Masyarakat Terhadap Minat Menabung Serta Dampaknya Kepada Keputusan Menabung Pada Perbankan Syariah Di Banda Aceh”, Jurnal Persoektif Ekonomi Darusalam, Volume 4, Nomor 1, Maret 2018. ISSN 2502-6976. 139

Zulkifli Zainuddin, Yahya Hamja, Siti Hamidah Rustiana, "Analisis Faktor dalam Pengambilan Keputusan Nasabah Memilih Produk Pembiayaan Perbankan Syariah (Studi Kasus pada PT Bank Syariah Mandiri Cabang Ciputat)", Jurnal Riset Manajemen dan Bisnis, Vol. 1, No. 1, (Juni,2016)

https://www.ojk.go.id/id/kanal/syariah/data-dan-statistik/statistik-perbankansyariah/Default.aspx di akses pada 31 Maret 2019. 